\title{
Metodyka budowy modeli facjalnych i petrofizycznych uwzględniająca warunki chronostratygraficznej przestrzeni depozycyjnej
}

\begin{abstract}
Niniejszy artykuł dotyczy analizy zasięgów i miąższości wykształceń facjalnych w ośrodku opisanym modelem facjalno-parametrycznym, skonstruowanym w przestrzeni depozycyjnej w celu precyzyjniejszego odtworzenia przestrzennej zmienności parametrów petrofizycznych w obrębie tych wydzieleń. Głównym celem była próba rozszerzenia standardowych procedur odtwarzania charakterystyki przestrzennej ośrodka geologicznego o analizy w warunkach depozycyjnych, w obszarze, w którym występuje zróżnicowanie facjalne. Skonstruowano dwa równorzędne warianty modelu strukturalnego: odnoszący się do warunków współczesnych i depozycyjnych utworów dolomitu głównego. Przedstawiono możliwości predykcji zmienności parametru zailenia, której zakres wartości nadzorowany był krzywymi zailenia pochodzącymi z czterech otworów. Model zailenia dolomitu głównego, odtworzony w przestrzeni depozycyjnej, jednoznacznie wskazuje, że materiał ilasty deponowany był głównie w obniżeniach, natomiast na wyniesieniach obserwowane są jego deficyty. Odtworzona zmienność zailenia we współczesnej geometrii utworów Ca2 $\mathrm{w}$ analizowanym obszarze ogranicza możliwość obserwacji prawidłowości w depozycji osadów ilastych z uwagi na deformacje tektoniczne, jakim ulegał basen sedymentacyjny dolomitu głównego. Natomiast model zailenia dolomitu głównego odtworzony w przestrzeni depozycyjnej jednoznacznie wskazuje trendy w depozycji materiału ilastego. Na podstawie stwierdzonych w oparciu o modele zailenia zależności przebiegu sedymentacji facji możliwa jest predykcja zasięgów poszczególnych wydzieleń facjalnych w obszarach objętych zdjęciem sejsmicznym, a nieprzewierconych otworami (np. w sąsiedztwie rozpoznanych złóż). Przedstawiona procedura przeznaczona jest dla obszarów o dużym zasięgu, charakteryzujących się obecnością różnorodnych środowisk sedymentacyjnych o odmiennym stopniu zailenia oraz obejmujących występowanie szeregu struktur, które mogą być potencjalnymi pułapkami dla akumulacji węglowodorów.
\end{abstract}

Słowa kluczowe: modelowanie facjalne, przestrzeń depozycyjna, dolomit główny.

\section{Facial and Petrophysical modeling based on chronostratigraphic depositional space}

This article concerns the concept of the range and thickness analysis of facies in a facial-parametrical model built in the depositional space, for the purpose of more accurately reconstructing the spatial variability of the petrophysical parameters within these subunits. The main goal, was an attempt of extending the standard procedures of reconstructing geological features of the geological medium for depositional analysis, in the area in which facial variation occurs. Two comparative variants of the structural model were constructed: referring to the contemporary and depositonal conditions of the Main Dolomite sediments. The possibility of predicting the variability of the clay content using seismic data whose range of variability was supervised by clay volume logs from four boreholes was presented. Clay content distribution model reproduced in the depositional space clearly indicates that the clay material is more likely to deposit in the depressions, while its shortages are observed within the elevations. By reproducing clay content variation in the present (modern) $\mathrm{Ca} 2$ geometry, due to the tectonic deformation of the Main Dolomite sedimentation basin, the depositional trends of clay deposit is not observed. Based on the observed clay distribution patterns of facies sedimentation, it is possible to predict the range of individual facies in the areas covered by a seismic data, not recognized by boreholes (e.g. in the vicinity of recognized hydrocarbon deposits). This concept is dedicated to large areas, characterized by the presence of various sedimentary environments containing clay material and the presence of a number of potentially hydrocarbon-rich structures. The presented procedure is dedicated to areas characterized by the presence of various sedimentary environments with variable clay content, including the occurrence of structures potentially accumulating hydrocarbons.

Key words: facial modeling, depositional space, Main Dolomite. 


\section{Wstęp}

Parametryczne modelowanie statyczne to zadanie wieloetapowe, którego celem jest odtworzenie przestrzennej zmienności cech fizycznych ośrodka geologicznego (wykształcenia litologicznego, facjalnego oraz zmienności parametrów zbiornikowych i filtracyjnych) w postaci modeli 3D, na potrzeby oceny atrakcyjności złoża pod kątem jego zagospodarowania $[8,9]$. Jednym $z$ istotniejszych etapów w procesie modelowania jest modelowanie facjalne, poprzedzone modelowaniem struktury złoża. Właściwa rekonstrukcja zasięgów facjalnych podnosi dokładność odtworzenia zmienności właściwości petrofizycznych w strefach o odmiennym charakterze litologicznym, co istotnie rzutuje na ostateczne wyniki, m.in. obliczeń zasobów. W ramach pracy badawczej przedstawionej w niniejszym artykule zaproponowano włączenie do przestrzennych analiz cech fizycznych ośrodka geologicznego elementu rekonstrukcji przestrzeni depozycyjnej jako czynnika podnoszącego wiarygodność odtwarzanej geometrii analizowanych wydzieleń/facji/subfacji na poszczególnych etapach rozwoju basenu $[1,5,6]$ (rysunek 1).

Ten niepraktykowany dotychczas w modelowaniu element poprzedzający przestrzenną charakterystykę cech fizycznych ośrodka stanowi rozszerzenie standardowych procedur (rysunek 2) o:

- rekonstrukcję reliefu dna zbiornika sedymentacyjnego oraz geometrii analizowanego interwału w czasie jego depozycji,

- odtworzenie zmienności zailenia w przestrzeni depozycyjnej,

- odtworzenie zasięgów depozycji kolejnych facji powstałych w różnych warunkach poszczególnych środowisk sedymentacyjnych.

Zailenie jest jedynym odtwarzanym przestrzennie parametrem złoża, który nie ulega $\mathrm{w}$ istotnym stopniu przemianom diagenetycznym (tak jak np. porowatość), wobec czego w zaproponowanej koncepcji zawartość materiału ilastego stanowi wskaźnik facjalny wspomagający ocenę zasobów zbiornika.

Analizowany w pracy przykład odnosi się do interwału dolomitu głównego obej- mującego strukturę złożową, zlokalizowaną w części wschodniej platformy północnej. Pomimo że przedstawiona jako cel pracy koncepcja ukierunkowana jest na obszary charakteryzujące się występowaniem różnorodnych środowisk sedymentacyjnych, analizowany jako przykład obszar cechuje się niewielkim, w skali całego basenu sedymentacyjnego cechsztynu, zasięgiem i zlokalizowany jest w obrębie jednej strefy depozycyjnej - w lagunie, w której, opierając się na doniesieniach literaturowych, spodziewać się można kilku subfacji [11- 13].

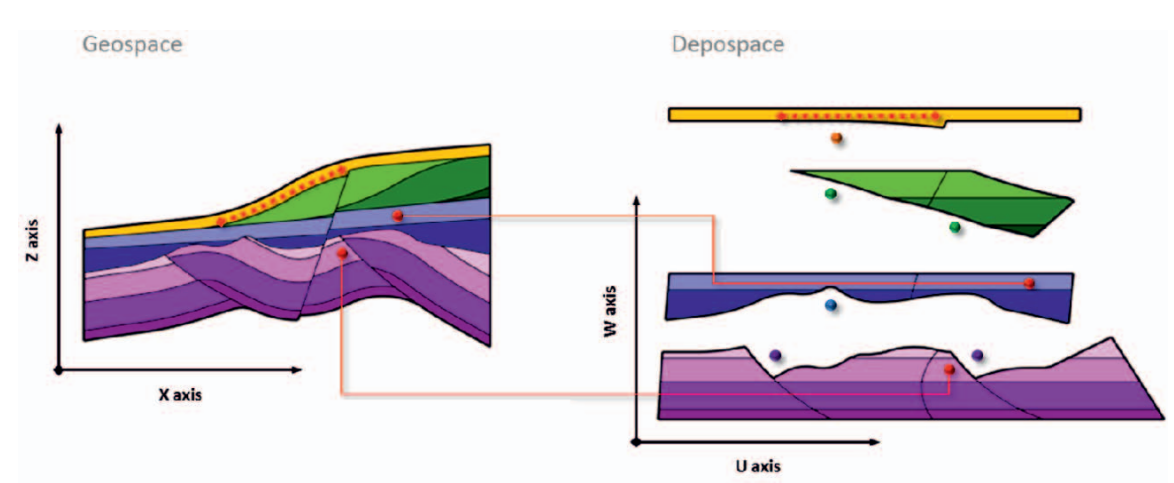

Rys. 1. Przykład rekonstrukcji przestrzeni geologicznej do geometrii po depozycji poszczególnych wydzieleń [5]

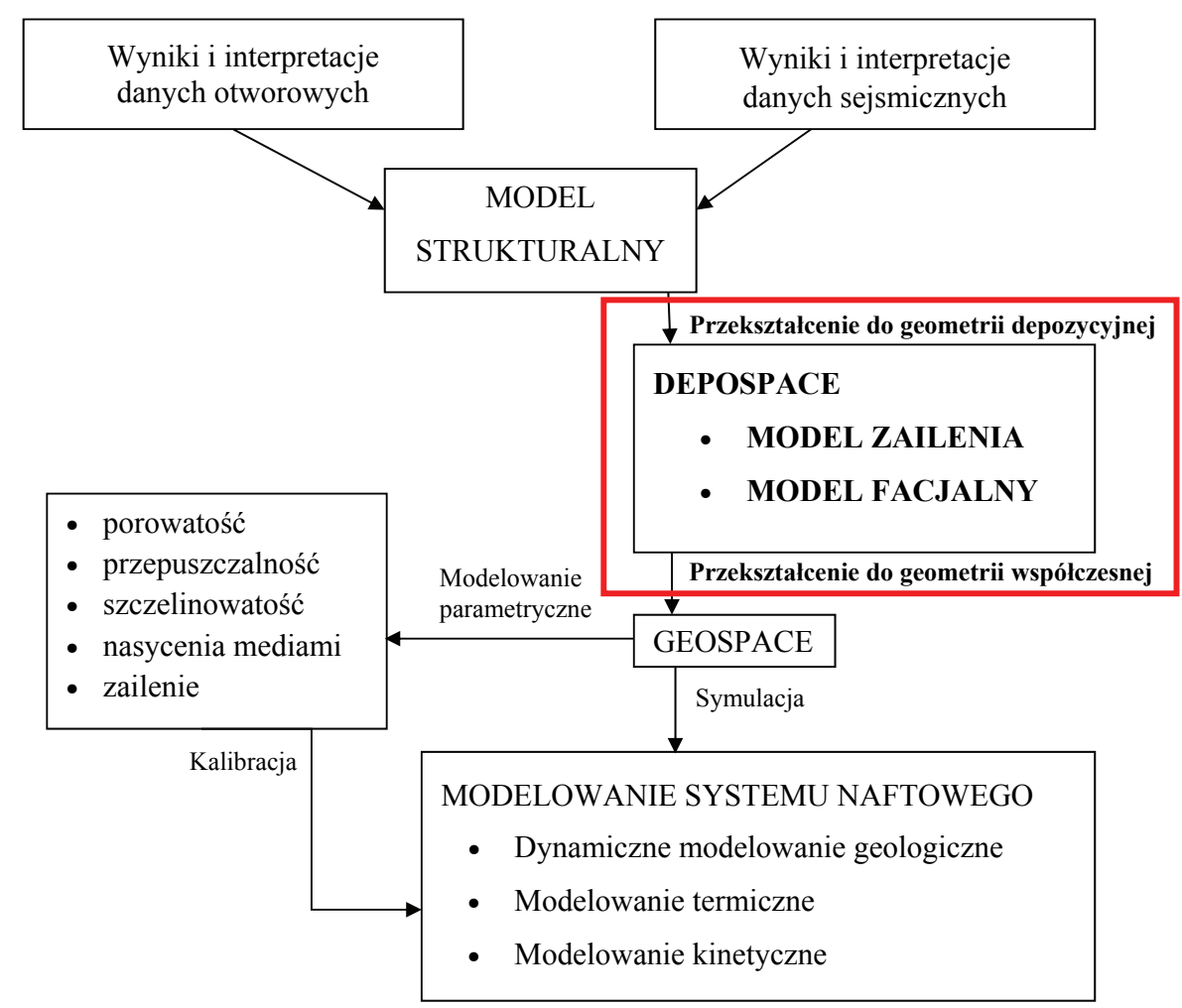

Rys. 2. Ogólny schemat poszczególnych etapów zadania odtworzenia przestrzennej charakterystyki obszaru geologicznego - rozszerzony o analizę zasięgów występowania facji w przestrzeni depozycyjnej 


\section{Modelowanie strukturalne}

W standardowym podejściu odtwarzania zmienności przestrzennej model strukturalny w niniejszym zadaniu byłby ograniczony wyłącznie do odwzorowania geometrii analizowanego interwału. Natomiast w celu odtworzenia geometrii interwału dolomitu głównego w przestrzeni depozycyjnej konieczna była rekonstrukcja strukturalna interwału o większym zasięgu pionowym, obejmującym $\mathrm{w}$ tym wypadku interwał soli Na2. Zakładając, że powierzchnie stropowe osadów solnych zalegają płasko, wypełniając deniwelacje terenu, przyjęto strop utworów soli najstarszej, zalegającej nad utworami dolomitu głównego i anhydrytu podstawowego A2, jako poziom wyrównujący. Dla celów porównawczych, definiując jednakowe parametry grida, skonstruowano dwa warianty modeli strukturalnych:

a) model dolomitu głównego - odwzorowujący obecną architekturę obszaru (rysunek 3A),

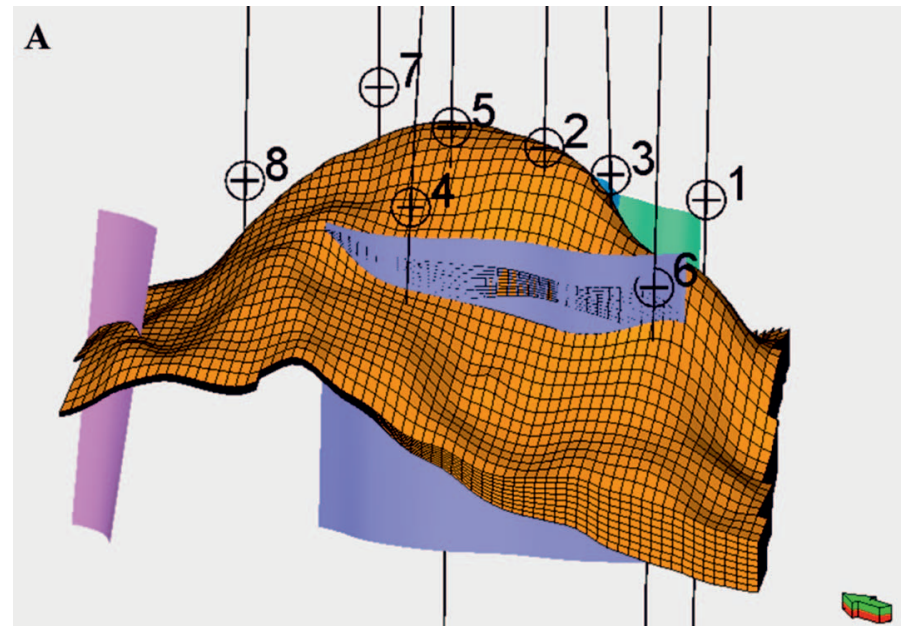

Rys. 3. A - model strukturalny dolomitu głównego w wariancie przestrzeni geologicznej; B - model strukturalny dolomitu głównego $\mathrm{Ca} 2$, anhydrytu podstawowego A2 i soli najstarszej Na2 $\mathrm{w}$ wariancie przestrzeni depozycyjnej B oraz jego wizualizacja we współczesnej geometrii B'. Numerami od 1 do 8 oznaczono lokalizacje otworów wiertniczych
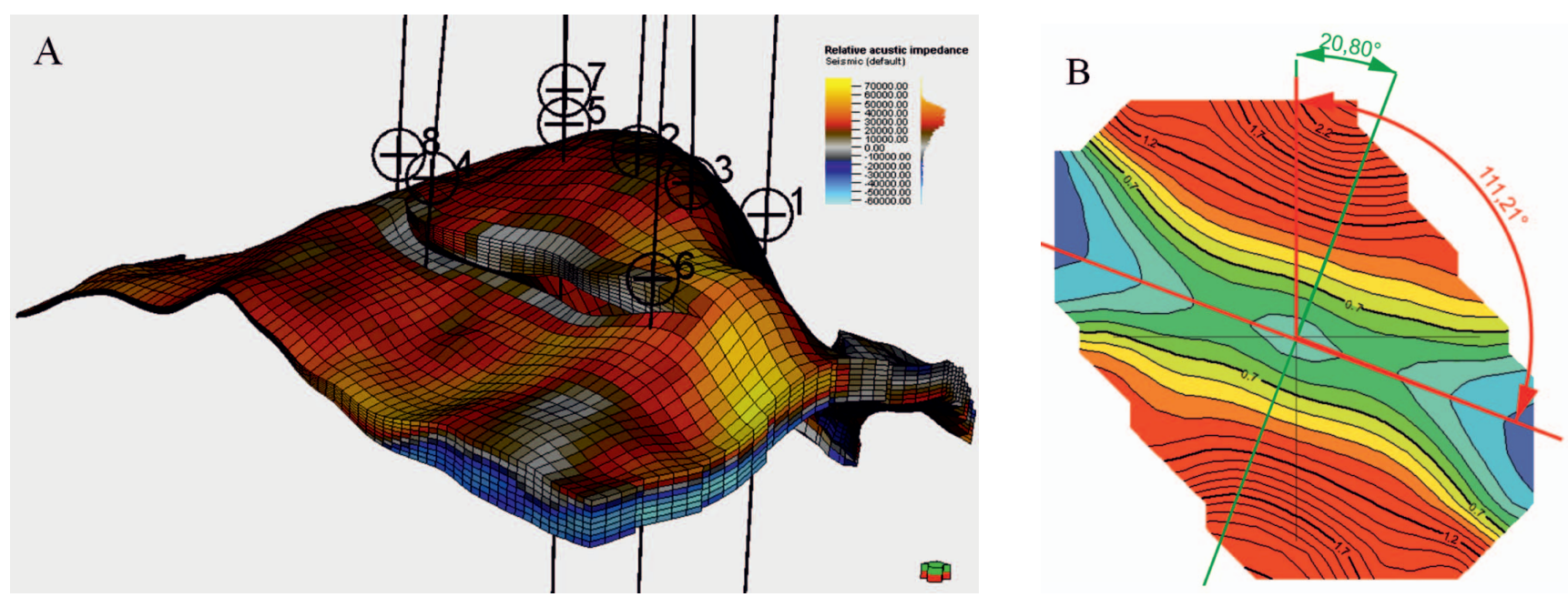

Rys. 4. A - Atrybut relative acoustic impedance, uśredniony w rozdzielczości grida; B - mapa wariogramu określająca główny i poboczny kierunek anizotropii w interwale dolomitu głównego 
wariogramu (rysunek 4B), na podstawie której określono kierunek największej kontynuacji wartości impedancji i tym samym główny kierunek anizotropii horyzontalnej jako azymut $111,21^{\circ}$. Kierunek najmniejszej kontynuacji zaznacza się prostopadle i wynosi $20,8^{\circ}$. Wartości te na etapie analizy danych poprzedzających modelowanie parametryczne zostaną zaaplikowane w celu określenia zasięgów odziaływania semiwariogramów w modelowaniu zailenia.

Przestrzenny rozkład zailenia został odtworzony na podstawie wyników interpretacji profilowań geofizyki otworowej w 4 odwiertach oraz wyniku inwersji genetycznej wolumenu sejsmicznego. Bimodalny charakter histogramu wartości zailenia (rysunek 5), uwzględniający dane w profilu otworów w interwale dolomitu głównego $\mathrm{Ca} 2$, sugeruje występowanie dwóch facji charakteryzujących się odmiennym poziomem zailenia. Informację tę wykorzystano na etapie definiowania przynależności komórek grida modelu zailenia w pierwszym etapie modelowania facjalnego.

W celu dostarczenia informacji o zmienności zailenia w przestrzeni między- i pozaotworowej zastosowano transformację wolumenu sejsmicznego, wykorzystując algorytm inwersji genetycznej. Inwersja genetyczna, łącząc elementy wielowarstwowych sieci neuronowych oraz algorytmów genetycznych, posłużyła do predykcji zmienności przestrzennej parametrów, które są wprost powiązane $\mathrm{z}$ amplitudą fal sejsmicznych [3, 4]. W niniejszej pracy wykorzystano tę technikę w celu odtworzenia przestrzennej zmienności zailenia w nterwale dolomitu głównego. Silna korelacja pomiędzy danymi otworowymi i obliczonym wynikiem inwersji genetycznej, na poziomie 0,71 , uzasadnia wykorzystanie przestrzennego wyniku na etapie geostatystycznej analizy danych. Zasadność wykorzystania danych sejsmicznych w celu odtworzenia przestrzennej zmienności zailenia powinna być podparta

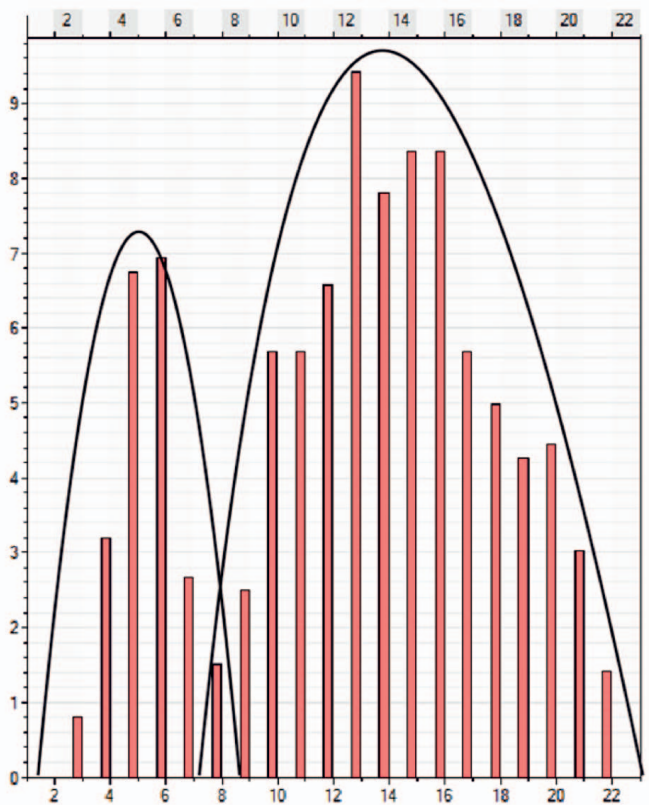

Rys. 5. Histogram zailenia

istnieniem odpowiednio silnej zależności pomiędzy danymi otworowymi i danymi sejsmicznymi (rysunek 6).

Dla wyznaczonych kierunków największej i najmniejszej zmienności wartości atrybutu relative acoustic impedance (rysunek 4A) określone zostały parametry semiwariogramów (w szczególności: typ modelu teoretycznego, zasięg stref oddziaływania jako odległość, przy której znika korelacja dla danego azymutu, wartość semiwariancji dla odległości mniejszej niż rozstaw opróbowania). W praktyce definiowanie semiwariogramów odbywa się w przestrzeni o regularnych kształtach komórek grida (simbox - rysunek 7 po lewej, oznaczone jako B). Tryb simbox ma za zadanie nadanie wszystkim komórkom jednakowych rozmiarów, a całemu gridowi regularnego kształtu w celu poszukiwania

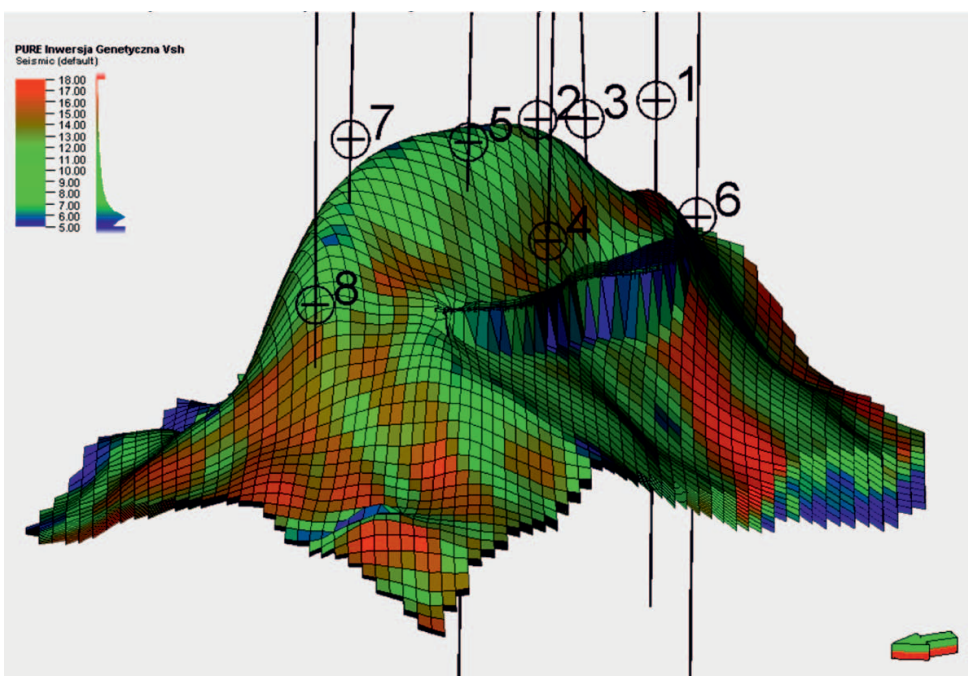

Rys. 6. Wynik inwersji genetycznej prognozującej rozkład zailenia w interwale dolomitu głównego. Zależność pomiędzy zaileniem wyinterpretowanym z danych geofizyki otworowej a inwersją genetyczną tego parametru

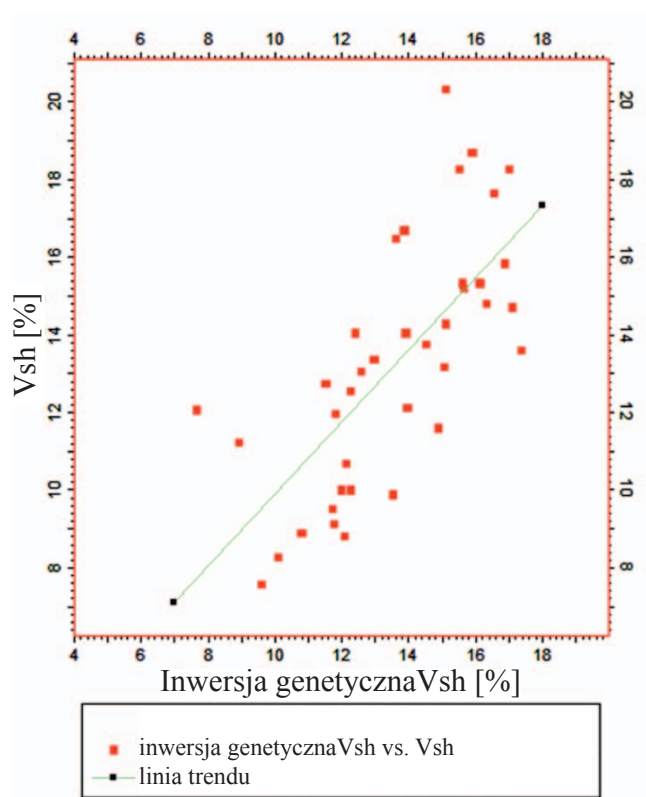


możliwie największych zasięgów kontynuacji wartości danej cechy złoża. W standardowym podejściu podczas analiz semiwariogramów zaleca się przełączanie geometrii modelu na tryb simbox, natomiast w niniejszej pracy zaproponowano analizę w geometrii rzeczywistej, co pozwoli na zdefiniowanie faktycznych zasięgów kontynuacji przestrzennej analizowanej cechy w pierwotnej geometrii złoża. Poniżej przedstawiono semiwariogramy (rysunek 8) odpowiadające wynikowi inwersji genetycznej w interwale dolomitu głównego dla kierunku głównego i pobocznego (prostopadłego do głównego) w wariantach (rysunek 7):

A. geometrii współczesnej-GEOSPACE,

B. geometrii współczesnej - grid o regularnych rozmiarach komórek - SIMBOX,

C. geometrii depozycyjnej-DEPOSPACE,

D. geometrii depozycyjnej - grid o regularnych komórkach

\section{- DEPOBOX.}

Różnorodność kształtów semiwariogramu demonstruje istotność wpływu wyboru geometrii, w której prowadzone są analizy. W klasycznym podejściu zasięgi kontynuacji dokładniej odzwierciedlone są na semiwariogramach w przestrzeni simbox. W tym przypadku zasięg w kierunku głównym $\left(110^{\circ}\right)$ wynosi $500 \mathrm{~m}$, natomiast w pobocznym $250 \mathrm{~m}$ przy semiwariancji 0,76 (wielkość grida to $3100 \mathrm{~m}$ na $1900 \mathrm{~m}$ ). W przypadku analizy zmienności w geometrii depozycyjnej faktyczne zasięgi prezentowane są na semiwariogramach C. Zasięg w kierunku głównym zdefiniowano na $440 \mathrm{~m}$, prostopadłym do głównego - $350 \mathrm{~m}$ przy semiwariancji na poziomie 0,71 . Uwzględnienie zdefiniowanych wartości semiwariogramu, wraz z innymi parametrami statystycznie charakteryzującymi dane (np. zdefiniowana krzywa dystrybucji wartości w modelu czy zakres zmienności), które aplikowane są na etapie modelowania parametrycznego, wpływa zasadniczo na wyniki końcowe rozkładu przestrzennego, w tym przypadku - parametru zailenia. Obserwując istnienie istotnej korelacji pomiędzy otworowymi profilami tego parametru a odpowiednio przekształconymi danymi sejsmicznymi, zastosowano jednoczesne aplikowanie obydwu źródeł danych (otworowych i wyniku inwersji) w procesie obliczania wynikowych modeli przestrzennych zailenia, w którym m.in. aplikowano zdefiniowane semiwariogramy.

Zmienność przestrzenną zailenia $\mathrm{w}$ obu przypadkach lepiej prezentują przekroje na rysunkach 10 i 11. Przebieg linii przekrojowych jest zgodny z azymutem kierunku pobocznego i głównego (rysunek 4B, kierunek poboczny - linia zielona, kierunek główny - linia czerwona).

W przypadku modelu odzwierciedlającego współczesną geometrię nie zaobserwowano prawidłowości w rozmieszczeniu zailenia, które z kolei w przypadku modelu odtwarzającego rozkład tego parametru w pierwotnej geometrii zaznaczają się podwyższonymi koncentracjami na skłonach wyniesień i obniżonymi wartościami w stropowej części wyniesienia.
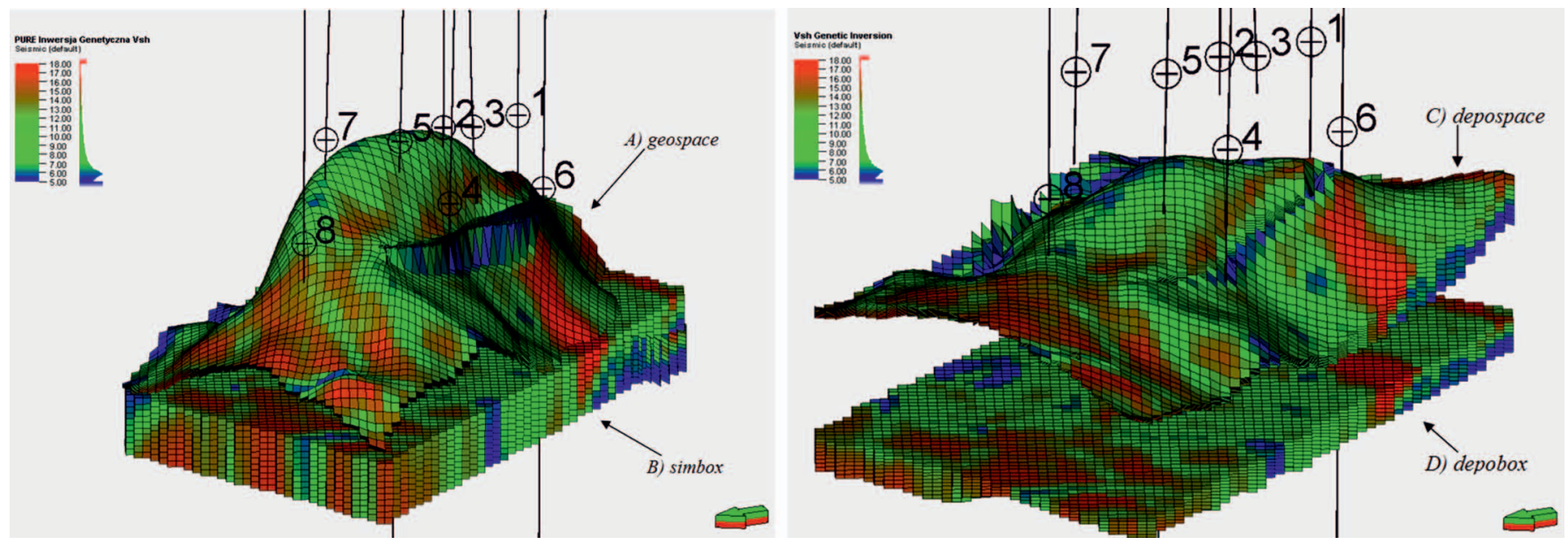

Rys. 7. Wynik przepróbkowania inwersji genetycznej do geometrii współczesnej (po lewej) i pierwotnej (po prawej)

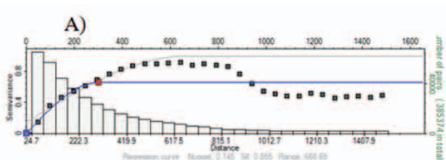

B)
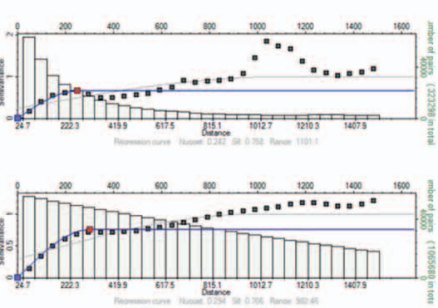
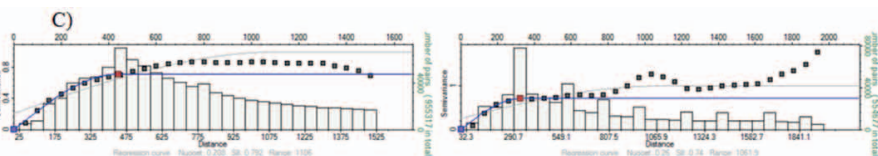

D)
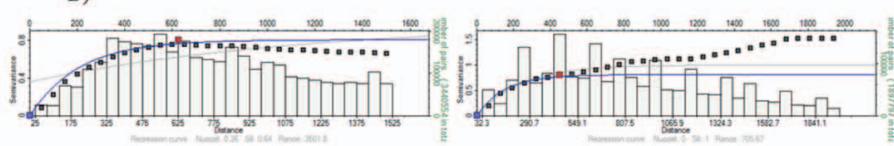

Rys. 8. Semiwariogramy dla wyników inwersji genetycznej zailenia dla wariantów modelu A, B, C, D w kierunku głównym (po lewej) i pobocznym (po prawej) 

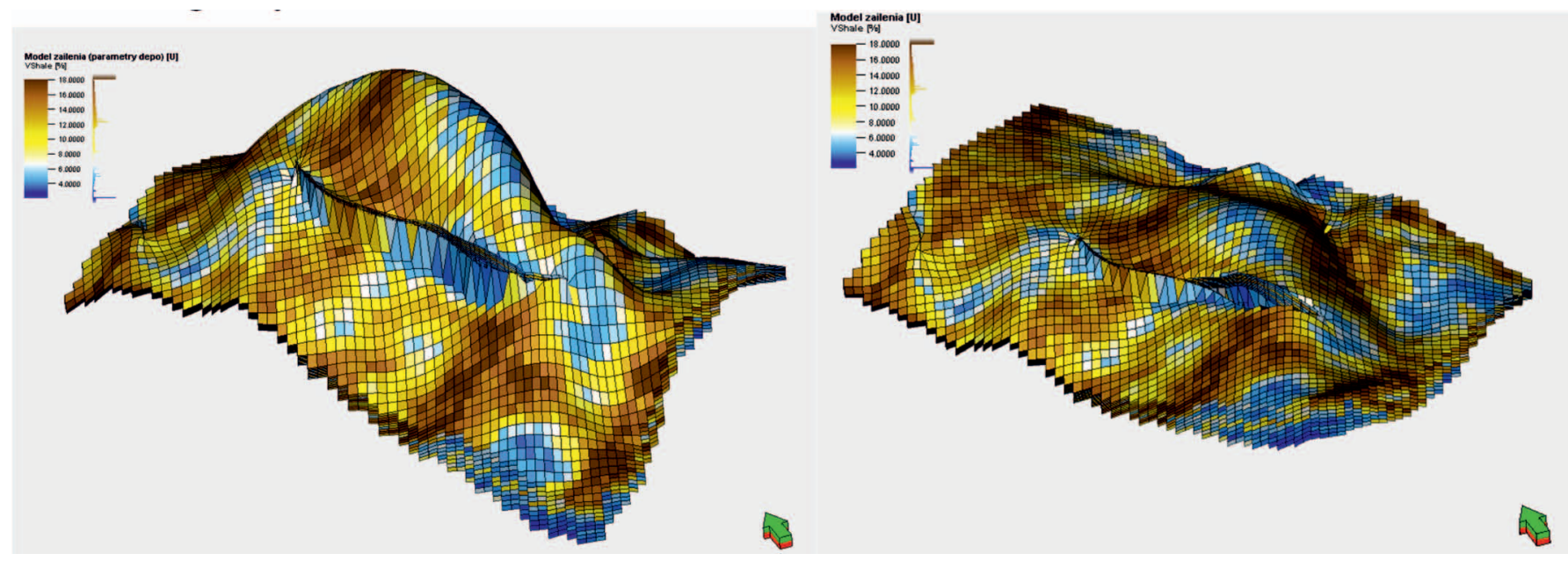

Rys. 9. Model zailenia dolomitu głównego współcześnie - po lewej (parametry wariogramu - rys. 8B)

i pierwotnie - po prawej (parametry wariogramu - rysunek $8 \mathrm{C}$ )

Paleowyniesienie widoczne w centralnej części profilu (rysunek 11 - dół), pomimo działalności tektonicznej, współcześnie zachowało formę wyniesienia, gdzie w obliczu m.in. występowania korzystnych właściwości zbiornikowych doszło do nagromadzenia gazu ziemnego. Wobec powyższego kolejnym
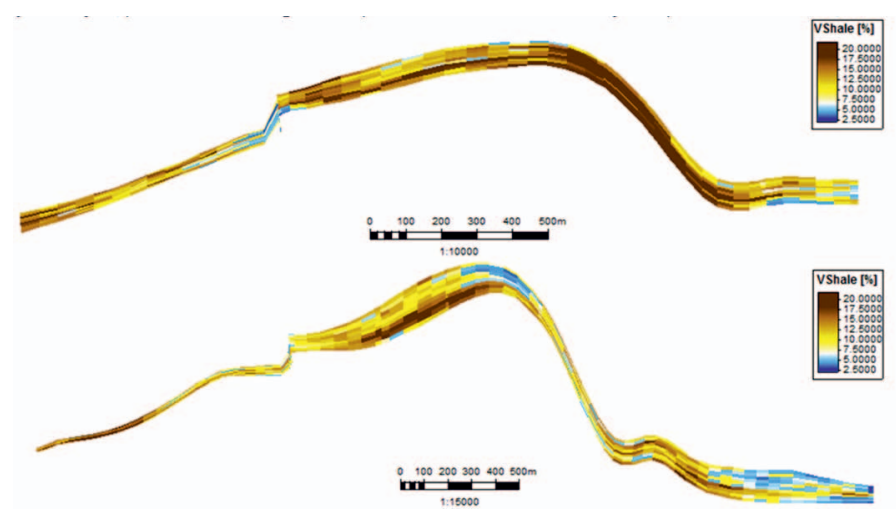

Rys. 10. Rozkład zailenia we współczesnej geometrii wzdłuż kierunku pobocznego (góra) i głównego (dół) etapem jest wyznaczenie, w całym zasięgu zdjęcia sejsmicznego, stref wyniesionych zarazem współcześnie i pierwotnie o sprzyjających właściwościach zbiornikowych przejawiających się niskim zaileniem, stanowiących potencjalne miejsca nagromadzeń węglowodorów.

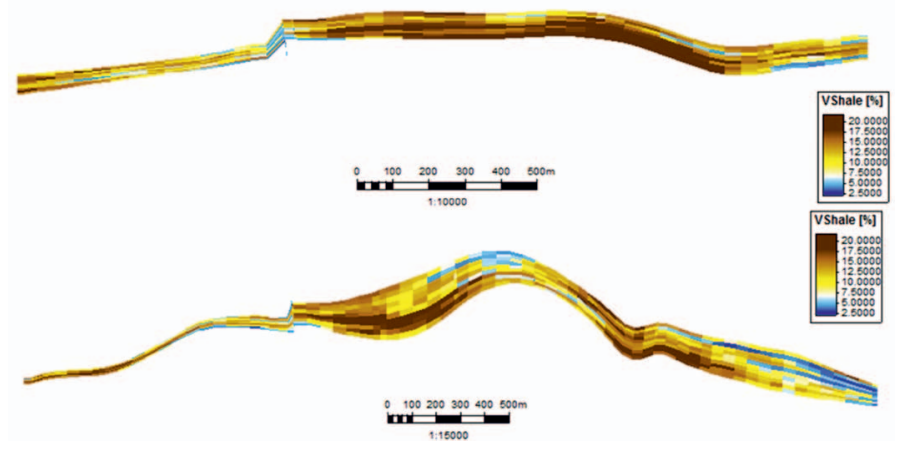

Rys. 11. Rozkład zailenia w pierwotnej geometrii wzdłuż kierunku pobocznego (góra) i głównego (dół)

\section{Modelowanie facjalne}

Modelowanie facjalne jest etapem pośrednim pomiędzy modelowaniem strukturalnym, obrazującym geometrię analizowanego obszaru, a modelowaniem parametrycznym [10]. W obliczu stwierdzonej zmienności facjalnej, charakteryzującej się zaznaczającym się zróżnicowaniem wartości parametrów petrofizycznych pomiędzy tymi facjami w obrębie analizowanego horyzontu, etap ten jest obligatoryjny dla precyzyjniejszego odtworzenia zmienności cech petrofizycznych związanych z określoną facją. Modelowanie facjalne, szczególnie w przypadku występowania kilku środowisk sedymentacyjnych, wymaga szczegółowej analizy sedymentologicznej i petrofizycznej poszczególnych litofacji opartej na analizie materiału rdzeniowego, interpretacji

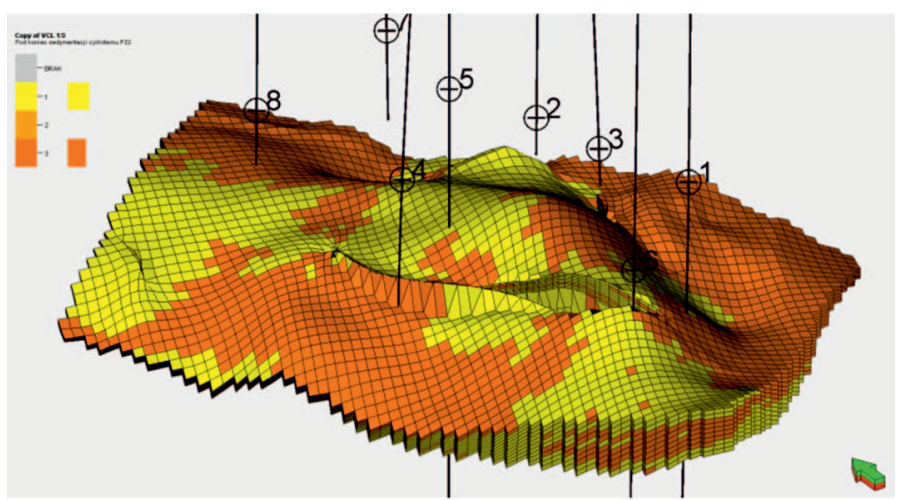

Rys. 12. Wynik modelowania facjalnego współczesnej geometrii dolomitu głównego w zasięgu analizowanego obszaru 
krzywych geofizyki wiertniczej oraz opracowania spójnej koncepcji rozwoju facjalnego.

Poniżej zaprezentowano równoczesne zastosowanie metod klasyfikacji oraz modelowania geostatystycznego. Wobec braku danych dotyczących różnorodności facjalnej analizowanego interwału, w celu zaprezentowania koncepcji, na podstawie kształtu histogramu zailenia (rysunek 5) wyodrębniono dwie populacje danych wynikające $\mathrm{z}$ bimodalnego charakteru wykresu. Obliczony model zmienności zailenia (w wariancie współczesnym i depozycyjnym) został przekształcony do postaci dyskretnej. Wartościom zailenia większym niż $8 \%$ przypisano kod 3 , natomiast wartościom mniejszym - kod 1 (rysunek 12).

Udział procentowy komórek grida o kodzie 3 (charakteryzujących się wartościami zailenia powyżej $8 \%$ ) stanowił $46 \%$, natomiast obszar o mniejszym zaileniu obejmował 56\% całego modelu. Na rysunku 13 przedstawiono mapy miąższości i zasięgów facji 1 i 3.

Znając relief dna zbiornika (rysunek 14A), na podstawie spójnej koncepcji sedymentologicznej należy zweryfikować, na ile opracowane mapy miąższości i zasięgów facji (rysunek 14B, B') odzwierciedlają spodziewane wyniki. W obliczu lokalnych niezgodności, niemających uzasadnienia w koncepcji rozwoju facjalnego, model należy poddać modyfikacjom, np. poprzez manualne korygowanie map, kierując się wszelkimi przesłankami dotyczącymi wykształcenia facjalnego.

Rys. 14. Opracowane wyniki modelowania w przestrzeni depozycyjnej: A - paleomorfologia dna zbiornika, B, B' - mapy zasięgów i miąższości

facji zdefiniowanych procentowym udziałem frakcji ilastej, C - paleomorfologia stropu facji 1, C' - paleomorfologia stropu facji 3 (przy założeniu chronostratygraficzności obu facji), D - strop dolomitu głównego (suma miąższości facji 1 i 3)

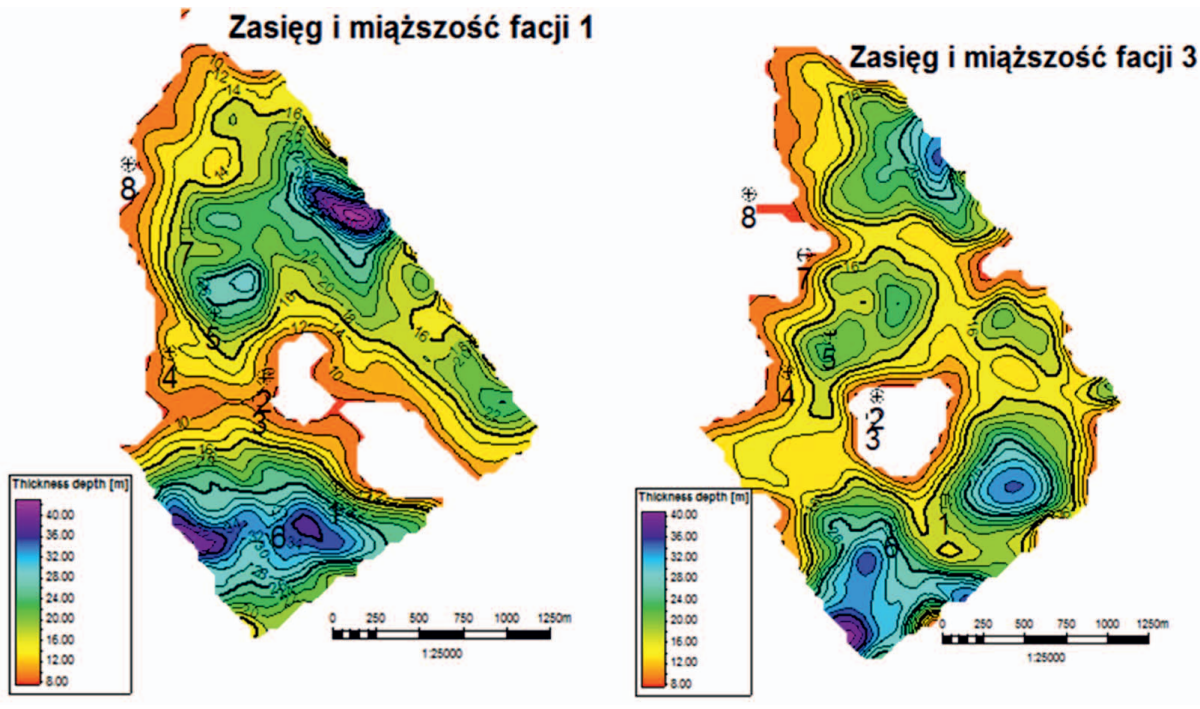

Rys. 13. Mapy miąższości i zasięgów facji zdefiniowanych w zasięgu analizowanego obszaru

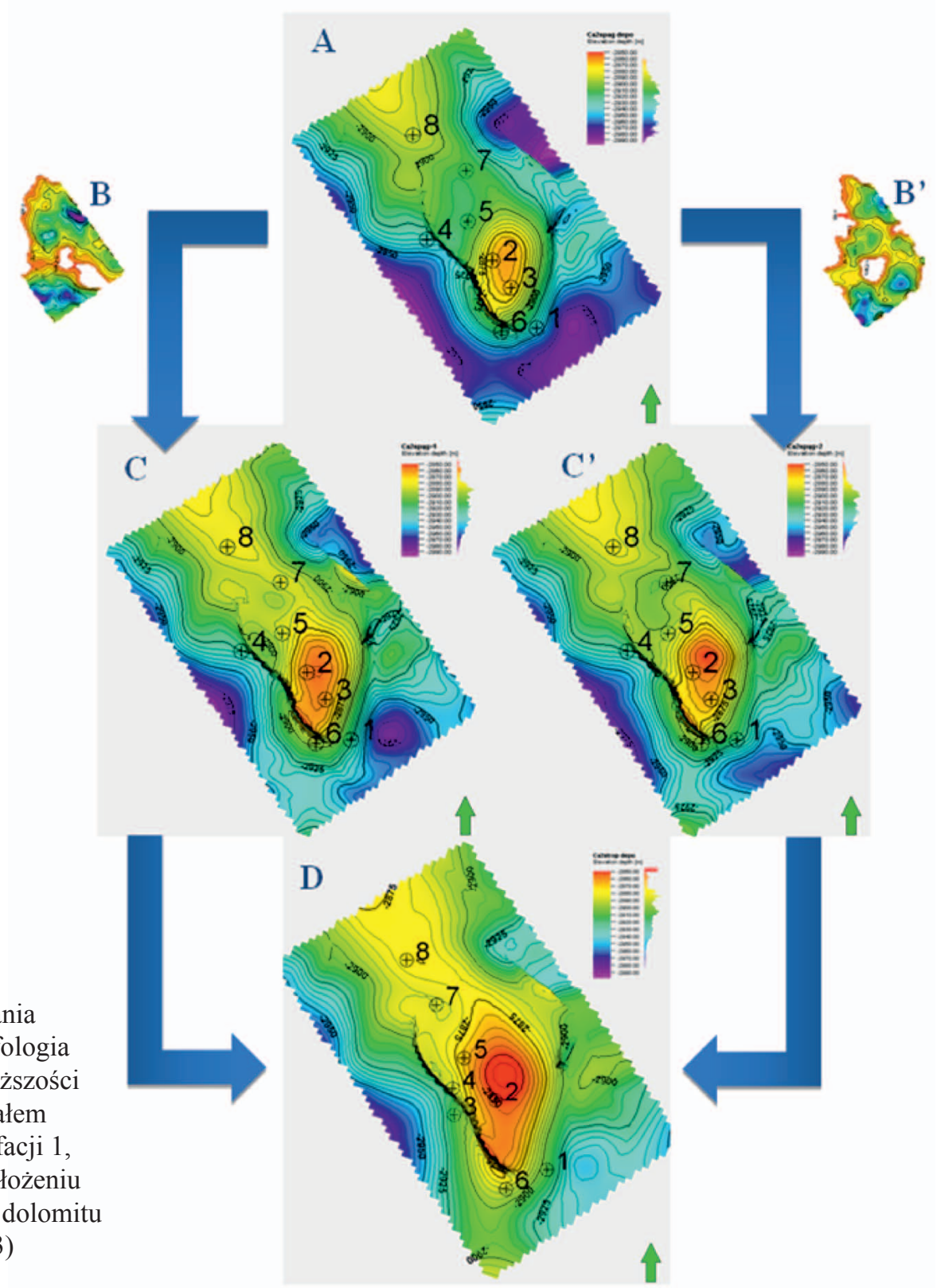




\section{Podsumowanie}

W artykule przedstawiono propozycję rozszerzenia standardowych procedur charakterystyki przestrzennej ośrodka geologicznego o analizy facjalne w warunkach depozycyjnych, sumarycznie pozwalające na precyzyjniejsze odtworzenie zmienności cech petrofizycznych w obszarze objętym zdjęciem sejsmicznym, poza strefą rozwierconą odwiertami, charakteryzującym się występowaniem facji o zaznaczającym się kontraście zawartości materiału ilastego oraz obejmującym występowanie szeregu struktur potencjalnie akumulujących węglowodory. $\mathrm{W}$ analizowanym $\mathrm{w}$ artykule obszarze wykazano trendy $\mathrm{w}$ preferencji depozycji materiału ilastego $\mathrm{w}$ paleoobniżeniach dna zbiornika sedymentacyjnego dolomitu głównego oraz deficyt zailenia (równoważny $\mathrm{w}$ tym przypadku z polepszeniem własności zbiornikowych) na paleowyniesieniach, które pomimo działalności tektonicznej nadal stanowią wyniesienia i pretendują do miana struktur potencjalnie akumulujących węglowodory.
W świetle przedstawionej koncepcji precyzyjniejszemu odtworzeniu zmienności facjalnej sprzyjać będzie dostępność:

- kompleksowej charakterystyki sedymentologicznej,

- wyników analiz materiału rdzeniowego, interpretacji danych krzywych geofizyki wiertniczej i danych sejsmicznych,

- danych sejsmicznych o rozdzielczości pionowej i poziomej pozwalającej uchwycić kontrast zawartości materiału ilastego [2],

- spójnej koncepcji rozwoju facjalnego analizowanego obszaru.

Przedstawiona analiza w połączeniu z modelowaniem parametrycznym i odtworzeniem procesów naftowych w rezultacie może przyczynić się do odkrycia obszarów o znaczącym potencjale złożowym poprzez zlokalizowanie akumulacji złożowych w facjach o korzystnych właściwościach zbiornikowych.

Prosimy cytować jako: Nafta-Gaz 2018, nr 10, s. 715-722, DOI: 10.18668/NG.2018.10.02

Artykuł nadesłano do Redakcji 5.12.2017 r. Zatwierdzono do druku 18.10.2018 r.

Artykuł powstał na podstawie pracy statutowej pt.: Metodyka budowy modeli facjalnych i petrofizycznych uwzględniająca warunki chronostratygraficznej przestrzeni depozycyjnej - praca Instytutu Nafty i Gazu - Państwowego Instytutu Badawczego na zlecenie Ministerstwa Nauki i Szkolnictwa Wyższego; numer zlecenia: 0038/SG/17, numer archiwalny: DK-4100-25/17.

\section{Literatura}

[1] Gringarten E., Arpat B., Jayr S., Mallet J.: New Geologic Grids For Robust Geostatistical Modeling Of Hydrocarbon Reservoirs. Eighth International Geostatistics Congress. Conference paper, 2008

[2] Jędrzejowska-Tyczkowska H.: Dobór optymalnej rozdzielczości sekcji sejsmicznej $w$ drodze analizy i modyfikacji charakterystyk spektralnych danych sejsmiki powierzchniowej i otworowej. Nafta-Gaz 2017, nr 8, s. 531-550, DOI: 10.18668/ NG.2017.08.01

[3] Jędrzejowska-Tyczkowska H.: Inwersja sejsmiczna akustyczna i elastyczna fal podtuznych, konwertowanych i poprzecznych $w$ zagadnieniach interpretacji złożowej. Prace Instytutu Nafty i Gazu 2009, nr 160, s. 1-85.

[4] Leginowicz A., Pirowska K.: Estymacja parametrów charakteryzujacych ośrodek geologiczny za pomoca procedury inwersji genetycznej. Nafta-Gaz 2013, nr 5, s. 392-400.

[5] Schlumberger: Petrel Property Modeling. Training and Excercise Guide. 2014.

[6] Souche L., Lepage F., Laverne T., Buchholz C.: Depositional Space: Construction and Applications to Facies and Petrophysical Property Simulations. International Petroleum Technology Conference. Conference Paper, 2015.

[7] Sowiżdżał K.: Studium metod analizy geostatystycznej w aspekcie optymalnego odtwarzania charakterystyki zbiornikowej podstawowych typów złóż węglowodorów. Rozprawa doktorska, WGGiOS AGH, Kraków 2013.

[8] Sowiżdżał K., Słoczyński T.: Dynamiczne modelowanie systemów naftowych $4 D w$ wybranych strefach basenu baltyckiego w rozpoznawaniu złóż węglowodorów w formacjach tupko- wych. Nafta-Gaz 2016, nr 12, s. 1018-1027, DOI: 10.18668/ NG.2016.12.02.

[9] Sowiżdżał K., Stadtmüller M., Lis-Śledziona A., Kaczmarczyk W.: Analiza porównawcza formacji tupkowych $w$ wybranych strefach basenu baltyckiego na podstawie interpretacji danych otworowych $i$ wyników modelowania geologicznego 3D. Nafta-Gaz 2016, nr 11, s. 891-900, DOI: 10.18668/ NG.2016.11.01.

[10] Sowiżdżał K., Stadtmüller M., Słota-Valim M.: Modelowanie facjalne i parametryczne jako narzędzie analizy i integracji spektrum danych geologiczno-geofizycznych. Przegląd Geologiczny 2014, vol. 62, nr 12, s. 818-824.

[11] Wagner R.: Charakterystyka facjalna i paleogeograficzna utworów dolomitu głównego. Archiwum BG Geonafta 2000.

[12] Wagner R.: Stratygrafia osadów i rozwój basenu cechsztyńskiego na Niżu Polskim. Prace Państwowego Instytutu Geologicznego 146, Warszawa 1994.

[13] Wagner R., Peryt T.M.: O możliwości podziału cechsztynu na sekwencje stratygraficzne w basenie polskim. [W:] Narkiewicz M. (red.): Analiza basenów sedymentacyjnych Niżu Polskiego. Prace Państwowego Instytutu Geologicznego 165, Warszawa 1998.

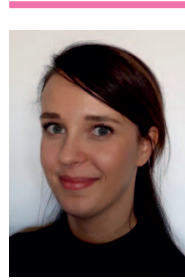

Mgr inż. Weronika KACZMARCZYK

Asystent w Zakładzie Geologii i Geochemii Instytut Nafty i Gazu - Państwowy Instytut Badawczy ul. Lubicz 25 A

31-503 Kraków

E-mail:weronika.kaczmarczyk@inig.pl 